\title{
MEMORIZING HABITS MODEL IN MUHAMMADIYAH 3 WARU JUNIOR HIGHSCHOOL
}

\author{
Noer Viatah, S.Pd \\ Muhammadiyah University of Sidoarjo \\ 188610800028 \\ Email : noerviatah1969@gmail.com
}

\begin{abstract}
Muslims are extremely privileged because they have a perfect role model Prophet Mohammad (SAW) to follow. He was the only person whose life was recorded and in his lifespan followed by his companions lately by the Muslim Ummah. The way of living and deeds of Prophet Mohammed (SAW) are the Sunnah Muslims are obliged to follow. Moreover, Muslims are being respected if they do the same thing to others card. Being a Muslim must follow Allah rules which has been given to Prophet Muhammad and also written in Qur'an. Qur'an is Holy Scripture of Muslims which is a collection of Word of Allah, who has sent to Prophet Muhammad. Qur'an contains clues for human race. The verse of the Qur'an has been preserved within the chest with memorized and understood by many Muslims are hereditary. Therefore, the ability to memorize the Qur'an is very important shared by all Muslims. One of efforts of improving the ability to memorize the Qur'an is using Qur'an memorization method.This study aims to describe memorizing habits model in Muhammadiyah 3 Waru Junior HighSchool. This research is intended to provide an overview for the memorizers of Qur'an regarding memorizing method that can provide assistance in reducing any difficulties in memorizing the Qur'an. The type of research used is field research with a qualitative approach. The data collection techniques are by observation, interviews, and documentation. The results of this study states that the memorizing habits model can run smoothly with Tikrar learning method and several other strategies. Habits model is carried out in a fun classical way so students do not get bored and feel burdened when memorizing. Habits model that has been carried out at Muhammadiyah 3 Waru Junior HighSchool is Tikrar (repetition) method, the Qur'an friendship, and tahfidz Qur'an.
\end{abstract}

Keywords: models of habituation, memorization, pledge, Qur'an, tahfidz, habit, tikrar, method, learning, adventure, qualitative approaches

\section{A. INTRODUCTION}

The learning process is the stages that are passed in developing someone cognitive, affective, and psychomotor abilities, in this case is the ability that must be possessed by students or students. One of the roles that a teacher has to go through these stages is as a facilitator. As a good facilitator, teacher must strive to optimally prepare learning designs that are in accordance with the characteristics of the students, in order to achieve the learning objectives.

In the learning process, there are reading and memorizing materials that must be used. Reading is an activity of perceptual, analyzing, and interpreting what is done by the reader to get the message to be conveyed by the author in the writing media. Reading activities include reading aloud and reading silently. Reading aloud is a reading activity carried out by reading aloud in public. While 
the activity of reading in the heart is the activity of reading carefully which is done to understand and understand the intent or purpose of the writer in the written media. ${ }^{1}$

Reading process is a fairly complex process that can be divided into 4 groups, namely breaking down symbols, literal understanding, inferential understanding, and monitoring. Reading is also very useful for: 1) Increasing vocabulary and knowledge of grammar and sentence order, 2) Able to imagine, and 3) Also useful for practicing writing.

Memorize or Memorizing comes from the word "memorized" which means "can be uttered with memory (no need to see the book)". If given the suffix "an" then it means learning about the lesson to memorize. And it also means "trying to apply into human mind to always remember". Memorize or Memorizing is a method that focuses on memory (memory type of learning). ${ }^{2}$

Therefore, the memorization method means a way of learning by using sharp memory to achieve a desired goal. Memory methods aim to strengthen memory.

According to Ballard, Briged and Clanchy, John memorization method aims for justification or re-mention of matter.

The importance of the memorization method is explained in the Al-Qur'an letter Al- A'la ayat 6-7 recites: ${ }^{3}$

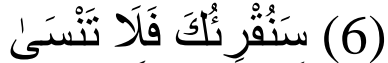

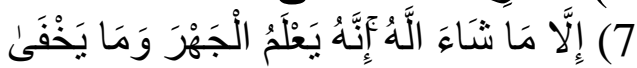

Meaning: We will recite (the Qur'an) to you (Muhammad) then you will not forget, unless Allah wills. Surely He knows the light and the hidden.

\footnotetext{
${ }^{1}$ Henry Guntur Tarigan, Membaca Sebagai Suatu Keterampilan Bahasa. Bandung: Angkasa, 1979 2 Abdul Azis Abdul Rauf Al Hafizh, Kiat Sukses Menjadi Hafizh Qur'an Da'iyah (Bandung: PT. Syaamil Cipta Media, 2004), hlm. 2

${ }^{3}$ Muhammad Shahib, Al-Qur'anulkarim terjemah Tafsir Perkata (Bandung: Sygma dan Syamil Quran, 2007).
}

From the above verse, it is clear that the importance of repeating from the Qur'an verses has memorized.

Thus, memorization method aims to strengthen memories that have been able to be repeated. In addition there are also habits method for memorizing easily and practically.

Besides, Reciting the Quran by heart and without reading the pages of the holy Book in a dream means proving to be true, or having a true claim, being pious, commanding what is good and forbidding what is evil.

Before the written verses were collected into the book we now know as the Qur'an, the passages were preserved in the memory of reciters. This practice has been passed down to this day, and around the world, young Muslim children memorize the Qur'an. Professional reciters perform for special occasions, such as festivals and funerals.

This study focuses more on memorizing habits model that has been implemented in Muhammadiyah 3 Waru Junior HighSchool since 2016 until now.

\section{B. RESEARCH METHOD}

This research method uses the method of learning carried out through data collection in the field, which provides an overview of the model learning and memorizing which is also obtained from the observation process. ${ }^{4}$

Learning models are developed from differences in student characteristics that vary. Because students have various personality characteristics, habits, ways of learning that vary between individuals with each other, the learning model is not fixed only on certain models.

Learning model according to Soekamto in Trianto (2009: 22) is a conceptual framework that describes systematic procedures in organizing learning experiences to achieve certain learning goals, and serves as a guide for learning designers

\footnotetext{
${ }^{4}$ Lexy. J. Meleong. Metodologi Penelitian Kualitatif, hlm. 247
} 
and instructors in planning teaching and learning activities.

In this case the method used is the Tikrar learning method. Tikrar learning is a form of systematization of how to memorize verses of Al-Qur'an and is widely practiced by the huffazh (penghafal Al-Qur'an), which started since old time. Tikrar learning is a form of repetition learning up to minimum 40 times that has done for generations since the time of the Prophet in the Nabawi mosque and Haram.

The purpose of using Tikrar Learning method is to mantain Qur'an memorization, because memorizing Qur'an is an order from Prophet Muhammad which has an ability of

Fard' Kifayah (comunally obligatory). Therefore, Tikrar learning method has the Best procedure, which is doing many repetitions when someone is reciting Qur'an.

Repetition is the key of success in memorizing, the more it spoken, the stronger it will be to remember. This is based on the history of Imam Al Bukhari which states that:

"I did not find a more effective way of memorizing other than by continually looking at writing and repeating statements, because that's actually memorizing"

This research approach uses a qualitative approach. The qualitative approach is carried out by describing existing data and then followed by analyzing the verse memorizing habit model that occurs during the learning process in the Muhammadiyah 3 Waru Junior HighSchool environment.

The research data is in the form of notes in the form of writings that have been transcribed from observations, documentation, and interviews. The source of data in this study is the process of teaching and learning (KBM) to memorize JUZ 30 at Muhammadiyah 3 Waru Junior HighSchool. The KBM process has taken place start in 2016.

\section{RESEARCH RESULTS}

In this research, it shows that memorizing habits model has done at Muhammadiyah 3 Waru Junior HighSchool. This habit is done in every learning subject, especially in memorizing Qur'an.

Muhammadiyah 3 Waru Junior HighSchool has been used Tikrar learning method. ${ }^{5}$ This method has used in a typical class. The class is classical class, which is a way for students and they do not get bored and feel burdened when memorizing many verses in the Qur'an.

In this case, the Qur'an is memorized repeatedly between ten and twenty times until it appears in the mind and reflexes in oral. Besides that, it uses several strategies such as:

1) Double repetition strategy

2) Do not switch to the next verse before the verse being memorized is truly memorized

3) Memorize the verse sequences that are memorized in one unit number after being completely memorized

4) Using one type of manuscript

5) Understanding the meaning of memorized verses

6) Pay attention to similar verses

7) He memorized it to the Tahfidz teacher

Those strategies work so well to the students and also help the teacher to add another verses from Qur'an.

Besides, the Qur'an teachers are also making goals and some rewards, when their students can fulfill the goals with the Best measurements. Thus can help students for being more confident and more dicipline to memorize and learn in reciting Qur'an.

\section{RESEARCH DISCUSSIONS}

Qur'an privillage is very extraordinary for instances making easy for the readers, memorizing, and understanding based on Word of Allah in surah Al-Qamar verse 17:

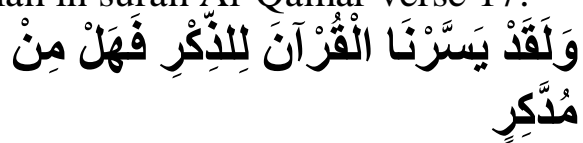

Means: 
And We have certainly made the Qur'an easy for remembrance, so is there any who will remember?

The memorisation of the Qur'an was important to Muslims in the past and is also in teh present. Yearly, thousands of students master the Qur'an and complete the book with interpretation and also memorisation.

Based on the statement above, it can be stated that Muhammadiyah 3 Waru Junior HighSchool has been doing Tikrar memorizing method since 2016. ${ }^{5}$ That method is also followed by several success strategies so that students memorize it pleasantly and without heavy burden.

All students were divided into several Halaqahs conducted by Tahfidz teachers. Then, the students get the Talaqii example which will be copied by students repeatedly up to 5 times while looking at the reading. After imitating, students will be asked not to see the reading while reciting them. After that, students will deposit their memorization, up to the emphasis of the verse by giving certain targets to the students, which are finally carried out in the evaluation stage.

Yet, not only that, there are several programs that must be followed by students, including Shohibul Qur'an, Morning Qur'an Recitations, Religious Studies, Daarul Arqam, Qur'an Safari Lovers, and Tahfidz Qur'an. Those program are so supporting for completing memorizing habits model successfully and gets the Best results that are in accordance with the specified target.

\section{Shohibul Qur'an}

Those who are active with Al-Quran besides being called ahlul Quran are also called shohibul Quran.

Shohibul Quran is a person who has an infinite love for Allah and the Prophet, so that he/she will never stop or come to stop

\footnotetext{
${ }^{5}$ Gade, Fitriani. 2014. Implementasi Metode Takrar Dalam Pembelajaran Menghafal Al-Qur'an. Vol.2. Didaktika. Februari 2014
}

reading the Qur'an. He/She is ready with the Qur'an until the end of his/her life.

Shohibul Quran is those who have faith in the hereafter as sure as the sun rises in the morning. So the Qur'an becomes a motivation to prepare a better afterlife. The peak goes to heaven, survived from hell. Only with this belief, *Shohibul Quran* will not run out of energy in interacting with the Qur'an.

Shohibul Quran is an ordinary human who has lust, sometimes lazy, bored, futur, sad, and so forth. But he/she never submitted to his/her desires for the sake of being with the Qur'an. His/Her determination was that today I was lazy, but I had to read the Qur'an, even though there were only 3 juz, so that when I got excited I could reach 5 juz or more.

\section{Allah ta'ala says in Ar-Ra'd verse 28}

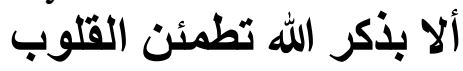

Means that: "Remember, only with the remembrance of God the heart becomes serene."

Becoming Shohibul Qur'an ${ }^{6}$ is the Best way to get update information about Qur'an. The information consist of reciting, memorizing method, and understanding course about Qur'an. Sometimes, Muhammadiyah 3 Waru Junior HighSchool has made a competition that relates to Qur'an Friendship, which is called as Musabaqa Tilawatil Qur'an.

\section{Morning Qur'an Recitations}

In school, it has an activity to recite Qur'an together. This activity has known as Morning Qur'an Recitations.

Recite and/or Memorize Quran as mentioned previously, or if you have a good tafsir book, then reading the meaning of at least one page of the Quran is a great bonus!

School Curriculum Leader has set that activity to help students for remembering

\footnotetext{
${ }^{6}$ Al-Qaradhawi, Yusuf. 2001. Berinteraksi Dengan AlQur'an. Jakarta: Gema Insani Press
} 
Qur'an. Therefore, they could not have any difficulties in reciting and memorizing.

Every morning, students must recite surah that has been choosen by Religion Teachers. Then, they are reciting it before they do and start school activities.

Thus can build a habit and also culture in the school, so students can memorize surah in easy and fast way.

This activity mentions in Al-Fajr verse 78:

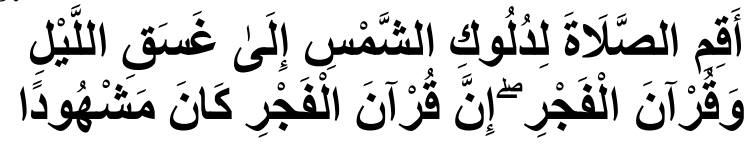

Means:

"Establish prayer from after the sun slips until the darkness of the night and (establish prayer) at dawn. Surely the morning prayer was witnessed (by angels)."

Based on the statement above, this is because Allah has singled out the Qur'an recited in the obligatory "Al-Fajr" prayer, giving it a special mention in the verse above. The morning time, is a great opportunity to bond with Qur'an and human brain is still fresh to get new information which relates with Qur'an.

\section{Religious Studies}

This study means that having community can be helpfull because it can have a discussion about Qur'an. The discussion has a mission of life that is in the diversity or plurality like the verse that reads. That statement also mentions in surah AlHujurat verse 13:

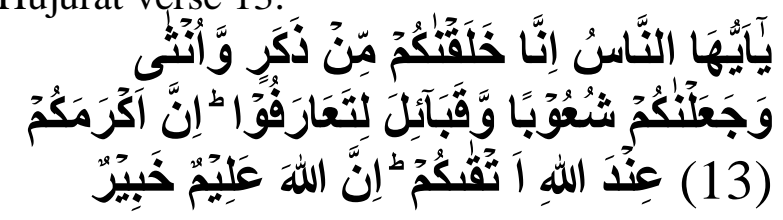

Means:

$O$ mankind, indeed We have created you from male and female and made you peoples and tribes that you may know one another. Indeed, the most noble of you in the sight of Allah is the most righteous of you. Indeed, Allah is Knowing and Acquainted.

\section{Daarul Arqam}

Daarul Arqam was also known as Daarul Khaizaraan. Daarul Arqam means a house which belongs to someone, who is one of Prophet friend. The person name is Arqam Bin Abil Arqam.

Arqam himself comes from Bani Mahzum which is an enemy of Bani Hasyim, a clan of Prophet Muhammad at that time.

Thus house has been used by Prophet Muhammad as a shelter for learning Islam. It was here that the following verse from Surah al-Anfal verse 64 was revealed:

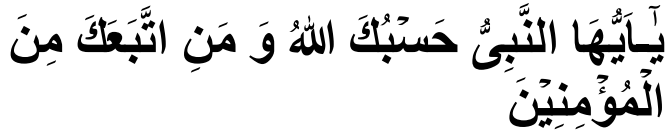

Means:

"O Prophet, Allah is sufficient for you, and for those who follow you among the believers." [Surah Al-Anfal verse 64]

\section{Qur'an Safari Lovers}

This activity forces students to travel different place for reciting Qur'an together with their friends.

It is very good and very helpfull because students can get refreshment in every week to recite and memorize Qur'an without making mistake. Then, they also feel fun and gain more confidences in their mind and heart.

Qur'an Safari is a part pf Islamic travelling. Travel makes the familiar unfamiliar to us and in doing so we come to better appreciate Allah's creation.

Travel creates a better you, because it takes you out of your comfort zone and forces you to ask questions about who you are, why you are and what you are. As Muslims we believe there will come a time when we have to stand alone in front of our Creator and be cross examined.

Travel allows you to cross examine yourself without the expectations of society, culture, religion and family. Those who have done this will tell you that nothing is more liberating than having only your own 
expectations. But be aware this can be quite scary the first time because you might suddenly realise that actually you don't have that many expectations of your own.

The Quran also says, "And if you travel in the land, there is no sin on you that you shorten your prayers (taqsurū min alsalät) if you fear that the unbelievers may harm you." [Sūrah Al-Nisā' :101].

\section{Tahfidz Qur'an}

Tahfidz Al-Qur'an consists of two words, namely tahfidz and Al-Qur'an. The word tahfidz is a form of masdar ghoir mim from the word حَفًَّ ـ يُخَفُِّ ـ تَحْفِيْظً which means memorizing. Whereas according to Abdul Aziz Abdul Rauf the definition of tahfidz or memorization is the process of repeating something, either by reading or listening. Any job if often repeated, must be memorized.

Thus mentions that memorizing the Qur'an is a process to maintain, preserve and preserve the purity of the Qur'an which is revealed to the Prophet. outside the head so that there is no change and forgery and can guard against forgetfulness either in whole or in part.

The purposes of Tahfidz Qur'an are 1) to create Quran memorizers, which have leadership thought and manner; 2) to improve children's thinking intelligence, namely careful and detailed sensing of an object and the accumulation of correct information about the object; 3) to train the sensitivity of the child's sense of hearing; 4) to train children to have high concentration; and 5) to help children easily understand the Qur'an (as a guide to life) and easily become taqwa.

Then, Tahfiz Qur'an looks like "as the first lesson for our children, then learning". The Qur'an itself comes from various fields of science, which is the main lesson for them.

Besides, the teachers are also giving tips to the students, start from:

1) Rise Up Early in the morning means that waking up and doing prayer at dawn can help for refreshing students mind to remember new surah effectively;
2) Set Realistic Goals and Memorize Less means that the teachers must set the goal so the students can feel it as a challange about the goal;

3) Every time to memorize means that the students must make notes about the Qur'an verse which is easily keeping in their pocket;

4) Recite what you memorize in every sholat, means that by reciting all the time after praying can be helpfull to remember it easily;

5) Find the silent place or distraction free environment, means that the students can memorize the Qur'an verses, if they can find silent place/quiet place which does not have crowded sound. So there is not any distraction for them.

Those tips above are always used by Qur'an teachers in Muhammadiyah 3 waru Junior HighSchool. Therefore, some schools program are working so well because of the efforts of the teachers.

\section{E. CONCLUSION}

This research is expected to contribute to scientific development and can also be a reference for other researchers. The success of memorizing habits model at Muhammadiyah 3 Waru Junior HighSchool is largely determined by the method and the memorize learning strategy itself.

In addition, there needs to be targets and readings that will make the benchmark for memorizing success.

Muhammadiyah 3 Waru Junior HighSchool has set target for the students to be a Hafidz and Hafidzah in memorizing JUZ 30 from Al-Qur'an.

Therefore, they use Tikrar Learning ${ }^{7}$ Method and establish six important programs to support Tahfidz Curriculum and also to support school mission and vission. The six programs are Shohibul Qur'an, Morning

\footnotetext{
${ }^{7}$ Gade, Fitriani. 2014. Implementasi Metode Takrar Dalam Pembelajaran Menghafal Al-Qur'an. Vol.2. Didaktika. Februari 2014
} 
Qur'an Recitations, Religious Studies, Daarul Arqam, Qur'an Safari Lovers, and Tahfidz Qur'an.

The benefits of Tikrar Learning Method is to keepp a good habit in memorizing Qur'an. The present of this study is for achieving target and the way of learning must be made of fun learning in order to help students for gaining the best result without having a huge burden in memorizing surah Al-Qur'an.

The class is in a classical way with some examples from the teachers and also give the students a chance to recite clearly after their memorize JUZ 30.

Based on the statement above, hopefully the method and the technique can be more helpfull to the students and the teachers to reach the goal fastly. The teachers also establish some tips for memorizing JUZ 30. The tips are 1) Rise Up Early in the morning; 2) Set Realistic Goals and Memorize Less; 3) Every time to memorize; 4) Recite what you memorize in every sholat; and 5) Find the silent place or distraction free environment.

Besides, the superiority of reciting the Qur'an is as valuable as prophetic favor. Memorizing the Quran is a worship and has an important subject and purpose. including 1) maintaining goodness; 2) maintaining the ambiguity of Islamic culture, 3) understanding the breadth of knowledge in the Quran, and 4) maintaining moral and social purity in society.

Last of all, the tips can be done for the students to learn, practice, and recite in anywhere and everytime without waiting an order from their teacher. Then, students' parents must help them to practice and encourage them at home.

Moreover, Muhammadiyah 3 Waru Junior HighSchool also needs to establish Tahfidz Program Management which is focusing the goal target and human resources, whether the qualified teachers and also the students. That can be followed by performing lots activities, competitions, and also learning materials, which is related to students cognitive, psychology fun, and desire to learn about Qur'an.

Therefore, learning Qur'an can be more fun and easy, ${ }^{8}$ if the teachers can be more creative and more dicipline in focusing the target for the students. In the Qur'an has lots of information and Science about Mankind social life and Islam, because Qur'an is to guide mankind to follow and find goodness as said in Al Baqarah verse 2:

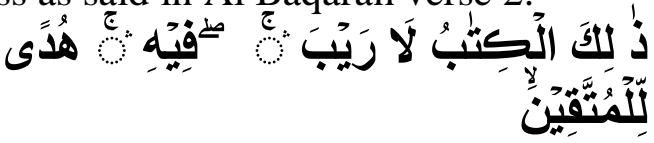

Means:

"This is the Book of Allah, there is no doubt in it; it is a guidance for the pious"

One obvious meaning of this verse is that this Book, the Qur'an, is undoubtedly from Allah. Another possible meaning is that nothing contained in it can be subject to doubt. Books which deal with supernatural questions, with matters that lie beyond the range of sense perception, are invariably based on conjecture and their authors, despite their brave show of competence, are therefore not immune from a degree of scepticism regarding their statements.

Al-Qur'an is based wholly on Truth, a Book which is the work of none other than the All-Knowing Allah Himself is distinguishable from all other books. Hence, there is no room for doubt about its contents despite the hesitation some people might express either through ignorance or folly.

Hopefully, we can start to memorize Qur'an and follow the tips as long as we can dicipline our mind and our heart, then we have to realize that making mistake is a part of learning, which can help us to gain better memorizing.

\section{REFERENCES Books}

\footnotetext{
8 Dahlan M.D. 2001 "Nilai Al-Qur'an dalam Memelihara Tutur Kata. Makalah Tanggal 4 Desember 2001
} 
Al-Hafidz, Ahsin .W. 1992. Bimbingan Praktis Menghafal Al-Qur'an. Jakarta: Bumi Aksara.

Al-Hafidz, Saiful Aziz. 2016. 60 Hari Hafal Al-Qur'an. Solo: Tinta Medina.

Al-Qaradhawi, Yusuf. 2001. Berinteraksi Dengan Al-Qur'an. Jakarta: Gema Insani Press.

Al-Qur'an dan Terjemahannya.1989 Departemen Agama RI.

Hafidz, Ahsin W al. 2005. Bimbingan Praktis Menghafal Al Qur'an. Jakarta: Bina Aksara.

Handayama, Jumanta. 2016. Metodologi Pengajaran. Jakarta: Bumi Aksara.

Hanani, Abu Bakar et al. 2004. Methods of Memorizing the Al-Qur'an. Kula Lumpur: Klang Book Centre.

Makhyaruddin, D.M. 2013. Rahasia Nikmatnya Menghafal Al-Qur'an. Jakarta: Noura Books.

Mazaaya, Abu Al-Hafiz. 2005. Fast and Easy Method of Memorization. New York: Al-Hidayah.

Moleong, Lexy J. 2011. Metodologi Penelitian Kualitatif. Edisi Revisi. Bandung: PT. Remaja Posdakarya.

Muhammad, Ahsin Sakho. 2016. Menghafal Al Qur'an Serasa Bermain Game dalam
Muqaddimah Metode Ilham. Bandung: Humaniora.

Sugiyono. 2015. Metode Penelitian

Pendidika: Pendekatan Kualitatif,

Kuantitatif, dan R\&D. Bandung:

Alfabeta.

Article Journals

Atabik, Ahmad. 2014. The Living Qur'an: Potret Budaya Tahfidz Al Qur'an di Nusantara. Dalam Jurnal Penelitian, Vol. 8, No. 1. 2014.

Hambal, Muhammad. 2015. "Deresan" Program the Mastery of Arabic-Classic Book at Pondok Pesantren Karangasem Lamongan East Java Indonesia. Journal of Social Sciences and Humanities, Vol. 1, No. 2, pp. 125-130

Gade, Fitriani. 2014. Implementasi Metode Takrar Dalam Pembelajaran Menghafal Al-Qur'an. Vol.2. Didaktika. Februari 2014.

Razaq, Abdur dan Deden Mula Saputra. 2016. Studi Analisis Komparatif Antara Ta'wil dan Hermeneutika Dalam Penafsiran Al-Qur'an. Journal Wardah: Vol.17 No. 2 (89-114). Wardah: Vol/Juli-Desember 2016 